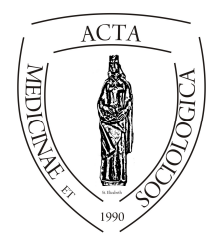

Acta Medicinae et

Sociologica (2020)

UNIVERSITY OF

DEBRECEN

Vol. 11., Különszám. (55-64)

FACULTY OF

HEALTH

doi:

NYÍREGYHÁZA

\title{
Egészségügyi dolgozók sportolási szokásai az Észak-alföldi régióban
}

\author{
Szépné Varga Henrietta ${ }^{1}$, Balatoni Ildikó ${ }^{2}$ \\ ${ }^{1}$ minőségbiztosító, Debreceni Egyetem Klinikai Központ Minőségügyi Iroda, 4032 Debrecen, Nagyerdei krt.98. \\ ${ }^{2}$ operatív igazgató, Debreceni Egyetem Klinikai Központ Operatív Igazgatóság, 4032 Debrecen, Nagyerdei krt.98.
}

\begin{tabular}{|c|c|}
\hline INFO & ABSTRACT \\
\hline $\begin{array}{l}\text { Dr. Balatoni Ildikó } \\
\text { balatoni@med.unideb.hu }\end{array}$ & \multirow[b]{2}{*}{$\begin{array}{l}\text { Abstract. The health of those working in health care institu- } \\
\text { tions is at risk from several aspects. However regular physi- } \\
\text { cal activity may play a role in counteracting these adverse } \\
\text { effects. During our research, we examined the sporting hab- } \\
\text { its of employees in one of the largest healthcare providers in } \\
\text { Hungary. The survey was conducted in a voluntary and } \\
\text { anonymous manner using a questionnaire method. } 45.1 \% \text { of } \\
\text { the } 987 \text { respondents does sport on a regular basis, at least } \\
\text { twice a week. We also examined the differences between the } \\
\text { various work groups - doctors, health workers, employees } \\
\text { of other sort - and those related to gender. } \\
\text { Based on the results it can be stated that health con- } \\
\text { sciousness still needs to be improved in the region, and an } \\
\text { especially important element of this can be the organized } \\
\text { health promoting activity of the health care institutions. }\end{array}$} \\
\hline $\begin{array}{l}\text { Keywords: } \\
\text { health industry, } \\
\text { employees, sports habits, } \\
\text { healthy lifestyle }\end{array}$ & \\
\hline $\begin{array}{l}\text { Kulcsszavak: } \\
\text { egészségügy, munkavál- } \\
\text { lalók, sportolási szoká- } \\
\text { sok, egészséges életmód }\end{array}$ & $\begin{array}{l}\text { Absztrakt: Az egészségügyi intézményekben dolgozók } \\
\text { egészsége több szempontból is kockázatnak van kitéve. } \\
\text { Ezen káros hatások ellensúlyozásában a rendszeres fizikai } \\
\text { aktivitás is szerepet játszhat. Kutatásunk során Magyaror- } \\
\text { szág egyik legnagyobb egészségügyi szolgáltató intézmé- } \\
\text { nyében vizsgáltuk a munkavállalók sportolási szokásait. A } \\
\text { felmérést önkéntes és anonim módon, kérdöíves módszer- } \\
\text { rel végeztük. A } 987 \text { válaszadónak } 45,1 \% \text {-a sportol rendsze- } \\
\text { resen, legalább heti két alkalommal. Vizsgáltuk a különbö- } \\
\text { ző munkaköri csoportok - orvos, szakdolgozó, egyéb mun- } \\
\text { kakörben foglalkoztatott -, valamint a nemek közötti kü- } \\
\text { lönbségeket is. } \\
\text { Az eredmények alapján megállapítható, hogy a régió- } \\
\text { ban továbbra is fejleszteni szükséges az egészségtudatos- } \\
\text { ságot, amelynek különösen fontos eleme lehet a munkálta- } \\
\text { tó egészségügyi intézmény szervezett formában megvalósí- } \\
\text { tott egészségfejlesztő tevékenysége. }\end{array}$ \\
\hline
\end{tabular}


A publikáció elkészítését az EFOP-3.6.2-16-2017-00003 számú projekt támogatta. A projekt az Európai Unió támogatásával, az Európai Szociális Alap társfinanszírozásával valósult meg.

\section{Bevezetés}

Egy ország lakosságának életminőségét és gazdasági teljesítőképességét az egészségügy jelentősen befolyásolja (Eke, Girasek és munkatársai 2009). Az egészségügyi ellátás megfelelő színvonala csak magasan képzett és élethosszig tartó tanulást vállaló munkaerővel valósítható meg. A szakképzett egészségügyi szakemberek hiánya komoly következményekkel jár mind az egészségügyi szolgáltatás minősége, teljesítőképessége, valamint költséghatékonysága szempontjából (Viszt 2006), de az egyenlő esélyü hozzáférést is korlátozza.

A WHO adatai szerint világszerte, így Európában is jelentős emberierőforráshiány figyelhető meg ezen a területen és a helyzet további romlása prognosztizálható (WHO, 2014, 2015). A KSH adatbázisa szerint (2014) Magyarországon az egészségügyi ágazatban több mint 40.000 orvos és további 100.000 ápoló és egyéb foglalkozású egészségügyi szakdolgozó végez munkát. A 20-59 év közötti lakosság számát (5,495 millió fó) tekintve ez - a mintegy 140.000 ember - 2,56\%-ot jelent, így az egészségügy az egyik legjelentősebb dolgozói létszámú szolgáltató szektor. Ugyanakkor azzal is szembe kell néznünk, hogy a müködéshez szükséges betöltetlen álláshelyeket tekintve 7800 dolgozó hiányzik a magyar rendszerből. A helyzetet súlyosbítja, hogy az egészségügyi pályát választók egészségmutatói szembetűnően rosszabbak a társadalmi átlagnál. Ehhez számos tényező járul hozzá, melyek közül az egyik, hogy az egészségügyi munkakörnyezet fizikai, kémiai, biológiai és ergonómiai kockázatokat jelent (Phiri, Drapr és munkatársai 2014). Ezek közzé tartoznak a mozgató szervrendszer terhelését jelentő hosszú mütéti beavatkozások, betegmozgatások, vagy a megnövekedett adminisztrációs terhek miatti irodai típusú ülőmunka, de a biológiai ágensekkel való kontamináció, a kémiai anyagokkal való érintkezés - ide értve a fertőtlenítéshez használt szereket, az anesztézia során alkalmazott gázokat, vagy az antibiotikumokat -, de ide értendő a radiológiai vizsgálatok kapcsán fellépő sugárzás is. Ugyancsak rizikófaktornak tekinthető a magas előfordulási arányú munkahelyi baleset - elcsúszás, elvágás, tüszúrásos sérülés, stb. -, valamint az egészségügyi dolgozókkal szemben előforduló agresszív viselkedés, fizikai bántalmazás is. Szintén ide tartozik a munkaidő beosztásból eredő terhelés és kimerültség. A sokszor napi 8 óránál hosszabb munkaidő, a szokatlan időben, váltakozó müszakban és munkaszüneti napokon történő munkavégzés hátrányosan befolyásolja a pihenést és a családi kapcsolatokat is. Az éjszakai munka is nagy megterhelést jelent. A munkaidő beosztáson túl tovább növeli a kockázatokat a nem megfelelő munkaszervezés, vagy a munkaerőhiány következtében fellépő túlórák magas száma, illetve a rendes munkaidő mellett vállalt ügyeletek. Tudományos adatok támasztják alá, hogy a váltakozó, többmüszakos és a hosszútávon, hosszú munkaidőben történő munkavégzés megnöveli az egészségügyi és szociális problémák kockázatát (Európai Unió 2013) és alvászavarokhoz, kardiovaszkuláris és metabolikus megbetegedésekhez valamint depresszióhoz vezethet. 
Az egészségügyi intézményben történő munkavégzés, a beteg emberek gyógyítása, ápolása a fentieken túl az egészségügyi személyzet számára erkölcsi- és jogi felelősség és jelentős érzelmi megterhelés is. Mindezek szerepet játszanak abban, hogy az ezen a területen dolgozók körében magasabb a halandóság és a kiégés (Győrffy és Ádám 2004, 2013; Molnár és Mezei 1991; Papp 2010; Vaillant, Sobowale és munkatársai 1972; Sonneck 1982; Shaw, Wedding és munkatársai 2001; Rurik, Szigethy és Langmár 2014).

Freudenberger (1974) írta le először a kiégést, mint jelenséget egészségügyi dolgozók vonatkozásában, majd Schmidbauer (1977) részletesen elemezte, hogy milyen tényezők játszanak szerepet ebben, egy segítő hivatás választása esetén (Csörsz, 2011). A kiégés során a személy és környezete egymásra hatása, a fizikailag és érzelmileg is megterhelö munka következtében az egyén rossz adaptációval válaszol a kihívásokra (Major, Ress és munkatársai 2006), és ennek eredményeként mind fizikai, mind érzelmi és lelki kimerültség tüneteit mutatja. A kutatási adatok az Egyesült Államokban és Európában is átlagosan 20\% körüli kiégési arányt jeleznek az orvosok körében (Reith 2018), - mely együtt járhat a gyógyító munka színvonalának romlásával (Dewa, Loong és munkatársai 2017) -, de természetesen az érintettek aránya változó országonként és szakterületenként (Alacacioglu, Yavuzsen és munkatársai 2009; Cubrilo-Turek, Urek és munkatársai 2006; Mannocci, Sestili és munkatársai 2019; Johns, Ossoff és munkatársai 2005; Ádám, Győffy és munkatársai 2010; Peterson, Demerouti és munkatársai 2008; Lacy és Chan 2018).

Már a 90-es években rámutattak a kutatók a rendszeres mozgás stressz, szorongás és depresszió kezelésében betöltött jótékony hatására (Hatfield, 1991; Norris,Carroll és munkatársai 1992; Steptoe, Moses és munkatársai 1993). A rendszeres fizikai aktivitás pozitív szerepet játszik a fizikai erőnlét, az egészség és a mentális jóllét fenntartásában, a depresszió prevenciójában (Detre 2007).

A gyógyításban részt vevő szakemberek és a betegek között kialakuló kapcsolat jelentős befolyásoló tényező a betegségek alakulásában és a gyógyító folyamatban (Csörsz, 2011). „Az orvos gyógyító munkájában azzal is gyógyít, hogy önmagából ad" (Bálint 1957). Ezzel egyidejüleg - mind az orvos, mind a nővér - példaként szolgál a betegek előtt. A kutatók eredményei azonban rámutatnak, hogy az egészséges életmód szempontjából az egészségügyi dolgozók bár beszélnek arról, hogy mi a helyes, ők számos esetben nem állhatnak/állhatnának mintaképként a lakosság számára (Blake és Harrison 2013; Blake, Malik és munkatársai 2011; Kirag, Ocaktan 2013; Al-Qahtani 2015; Kay, Mitchell és De Mar 2004).

A fentiekre tekintettel kutatásunk során arra voltunk kíváncsiak, hogy Magyarország egyik legnagyobb egészségügyi intézményének dolgozói milyen életmódot folytatnak, milyen gyakran sportolnak.

\section{Anyag és módszer}

Kutatásunkat 2019 tavaszán, a Debreceni Egyetem Klinikai Központjában dolgozó orvosok, szakdolgozók és egyéb munkakörben foglalkoztatottak körében végeztük, 
kérdőíves módszerrel. Az egyes kérdések a szocio-demográfiai adatokon túl, a sportolási szokásokra, a sportolás gyakoriságára, annak motivációira vonatkoztak. A felmérésben 987 dolgozó vett részt, mely a dolgozói összlétszám 31\%-a. A kitöltés önkéntes és anonim volt. Az adatok feldolgozása EvaSys (VSL Inc., Hungary; http://www.vsl.hu) programmal történt. Az adatok bemutatása során, minden esetben, az átlagot \pm SD tüntettük fel. Szignifikánsnak azokat a különbségeket tekintettük, ahol $\mathrm{p}<0,05$.

\section{Eredmények}

A Debreceni Egyetem Klinikai Központjában közel 3100 fö dolgozik. A több mint 660 orvos, 2000 szakdolgozó és 400 egyéb munkakörben foglalkoztatott évente majdnem százezer fekvő- és egymillió járóbeteg ellátását biztosítja. 2018-ban mintegy 480.000 ápolási nap és 300.000 szakorvosi munkaóra teljesítésére került sor. Az intézmény munkatársai felelősek több mint 1,2 millió ember - Hajdú-Bihar, Szabolcs-Szatmár-Bereg, valamint Jász-Nagykun-Szolnok megye és Borsod-AbaújZemplén megye bizonyos területei lakosságának - egészségügyi ellátásáért. Munkájuk, mindennapi helytállásuk nélkülözhetetlen a biztonságos betegellátás érdekében.

A kérdőívet kitöltő 987 fö 16,2\%-a orvos, 65,5\%-a szakdolgozó és 18,2\%-uk

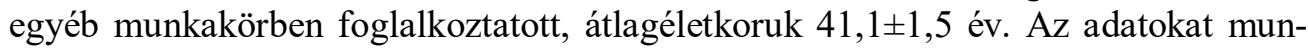
kaköri csoportonként vizsgálva megállapítható, hogy a szakdolgozók átlagéletkora 40,5 $\pm 1,9$ év, az orvosoké 37,5 $\pm 3,9$ év, az egyéb munkakörben dolgozóké 41,0 $\pm 3,6$ év. A válaszadók életkorának eloszlását az 1 . ábra mutatja.

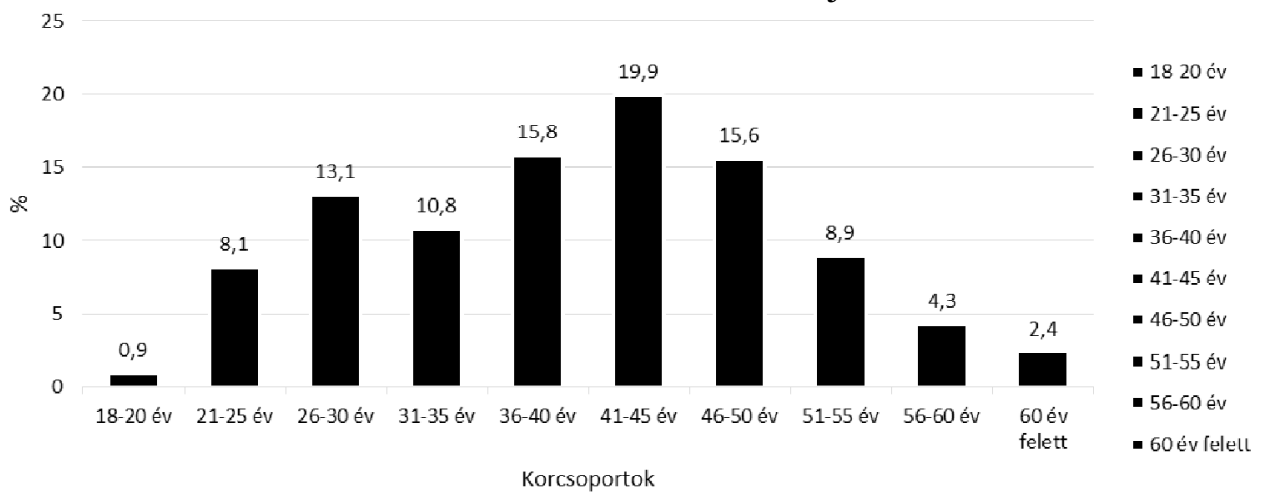

(Forrás: Saját szerkesztés)

1. ábra. A dolgozók életkorának megoszlása (\%)

A válaszadók 78,4\% nő, 21,6\%-a férfi. A nemek munkakörönkénti megoszlását az 2. ábra szemlélteti. Míg az orvosok esetében közel azonos a női-férfi kitöltők aránya, addig a szakdolgozók esetében és az egyéb munkakörben dolgozóknál a női munkaerő túlsúlya figyelhető meg. 


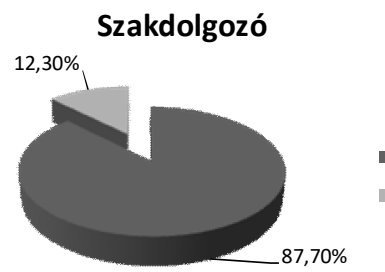

Orvos

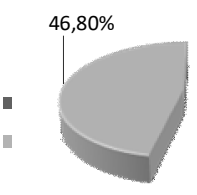

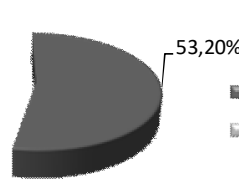

Egyéb munkakör

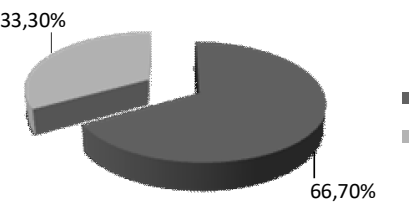

(Forrás: Saját szerkesztés)

2. ábra. A válaszadók nemenkénti megoszlása munkakörök szerint

A családi állapotot tekintve, valamennyi munkaköri csoportban a kitöltők kicsivel több, mint fele, 51-55\%-a házasságban él. A fennmaradók közül legtöbben még egyedülállók (hajadon, nőtlen), mely csoport különösen számottevő az orvosok esetében $(40,3 \%)$.

A lakóhelyet vizsgálva megállapítható, hogy míg az orvosok közel 90\%-a debreceni, addig a másik két munkaköri csoport esetében magasabb (33-37\%) a más településekről bejárók aránya.

A válaszadók 37,8\%-a napi 8 órában, 39,1\%-a folyamatos munkarendben (12 órában) dolgozik, 23,1\%-uk ad készenlétet vagy ügyeletet a napi munkaideje mellett.

A kitöltők, saját megítélésük szerint, hétköznap átlagosan 4,0 óra, hétvégén 5,5 óra szabadidővel rendelkeznek, amely a munkavégzés és az egyéb feltétlenül szükséges elfoglaltságok idején túl fennmaradó olyan szabad felhasználású idő, amely a kikapcsolódást, felfrissülést szolgálja. A nők mind hétköznap $(3,9 \pm 1,8$ vs 4,3 $\pm 2,2$ óra; $\mathrm{p}<0,02)$, mind hétvégén $(5,3 \pm 2,2$ vs $6,0 \pm 2,4$ óra; $\mathrm{p}<0,001)$ szignifikánsan kevesebb szabadidőről számoltak be, mint a férfiak.

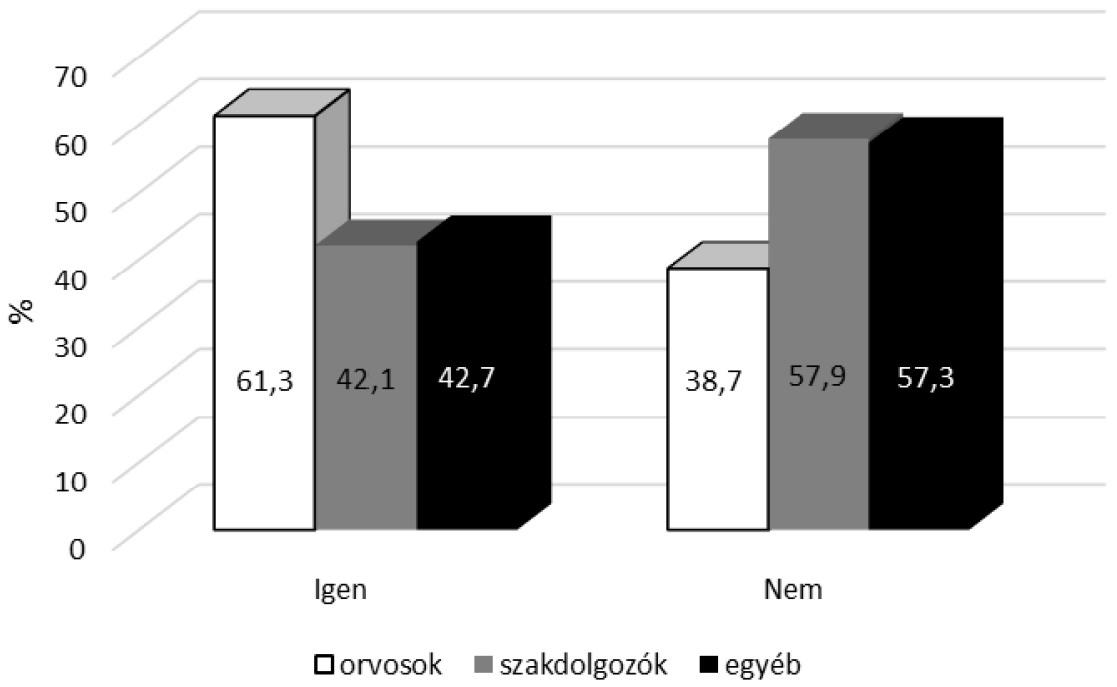

(Forrás: Saját szerkesztés)

3. ábra. Sportolás megoszlása munkakörönként 
Az érintett dolgozók 45,1\%-a mondta azt, hogy rendszeresen a sportol (legalább 30 perc folyamatos fizikai aktivitás, hetente legalább 2 alkalommal). Az orvosok 38,7\%-a, a szakdolgozók 57,9\%-a és az egyéb az munkakörben dolgozók 57,3\%-a nem végez rendszeres fizikai aktivitást (3. ábra).

A sportolás gyakoriságát vizsgálva megállapítható, hogy a rendszeresen sportoló válaszadók 50\%-a hetente 2 alkalommal, további 36,9\%-a heti 3-4 alkalommal végez ilyen jellegü tevékenységet (4. ábra).

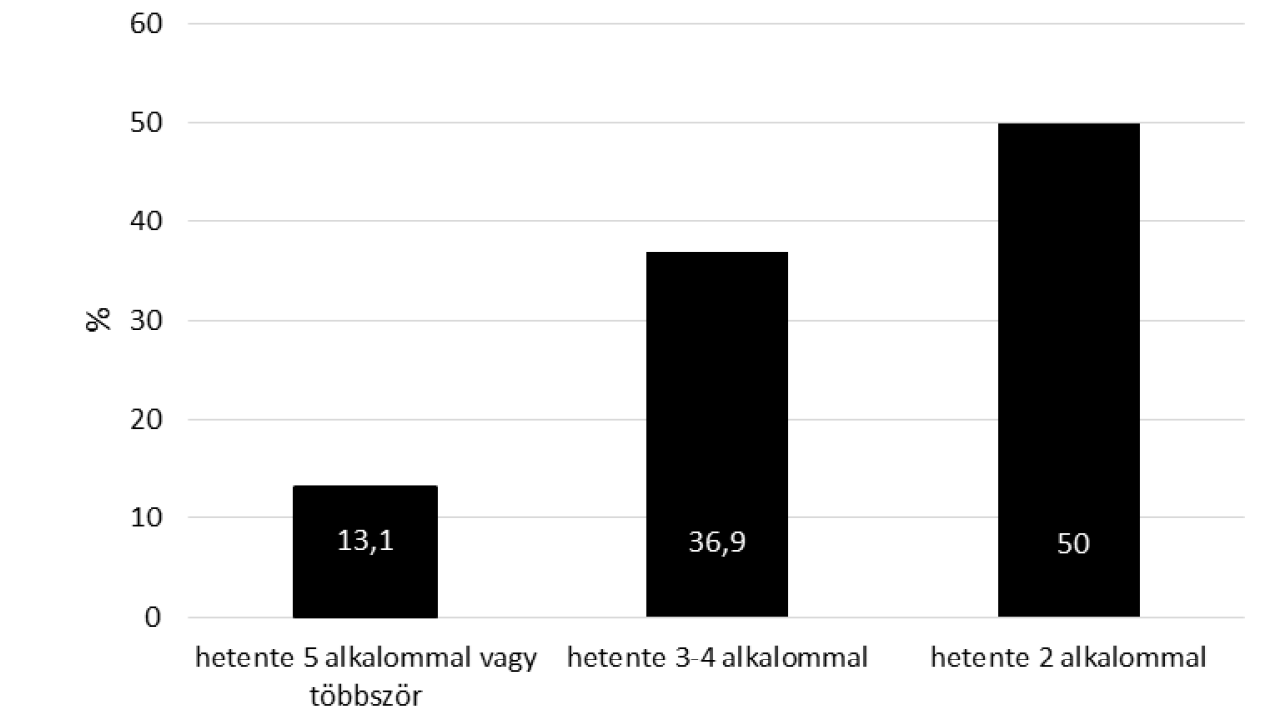

(Forrás: Saját szerkesztés)

4. ábra: Sportolási gyakoriság

A választott sportágakat elemezve megfigyelhető, hogy az orvosok elsősorban a futást, a kondicionálóteremben végezhető edzést, valamint a kerékpározást részesítik elönyben. A szakdolgozók és az egyéb munkakörben dolgozók körében első helyen a kerékpározás áll. Az orvosok 4. leggyakrabban választott sportja az úszás, ezzel szemben ez a sportág se a szakdolgozók, se az egyéb munkakörben dolgozók körében nem népszerü, helyette inkább tornázni járnak.

Míg az orvosok közel fele (44,2\%) leggyakrabban egy sportklubot, sportlétesítményt választ sportolása helyszínéül, addig a szakdolgozók és az egyéb munkakörüek inkább otthonukat és/vagy a szabadtéri lehetőségeket preferálják.

A megkérdezettek 10,1\%-a sportegyesület tagja, és 12,8\%-uk szokott versenyeken részt venni.

A három munkakört külön is megvizsgálva megállapítható, hogy a motivációt tekintve egyöntetüen a legtöbben a „hogy fenntartsam az erőnlétemet és egészségesebben éljek”, „szükségem van a testmozgásra, hogy jól érezzem magam a bőrömben" válaszokat jelölték meg. A fizikai inaktivitás okaként valamennyi munkakör esetében az időhiány és a fáradtság a leginkább befolyásoló tényező. 
Az egészségi állapotra, közérzetre vonatkozóan is tettünk fel kérdéseket. A válaszokból kiderült, hogy a munkatársak gyakorta éreznek kimerültséget $(54,3 \%)$ és derékfájást $(58,7 \%)$, valamint 40,0\%-uk alvási problémákkal is küzd.

A kimerültség a nők körében szignifikánsan gyakoribb, mint a férfiaknál $(\mathrm{p}<0,001)$, ezzel párhuzamosan a derékfájás a szakdolgozók körében fordul elő nagyobb valószínüséggel ( $\mathrm{p}<0,01)$, mint az orvosoknál.

\section{Következtetés}

Az egészségügy területén dolgozók - ide értve az orvosokat, szakdolgozókat és az egyéb munkakörben foglalkoztatott szakembereket is - egészsége a fokozott megterhelés következtében nagyobb kockázatnak van kitéve. A munkában töltött idő elörehaladtával egészségi állapotuk az átlagosnál gyorsabban romolhat, ami kedvezőtlenül befolyásolhatja munkavégző képességüket. Az egészségügyi dolgozók munkahelyén emiatt az egészségtudatos intézkedések még inkább indokoltak és szükségesek. Egészségük az ágazati foglalkoztatási gondok, a munkaerőhiány problémái szempontjából kiemelkedő jelentőséggel bír, és így az egészségügyi ellátás színvonalának biztosítása érdekében is fontos tényező (Terebessy- Matyasovszky és munkatársai 2016).

A hazai munkáltatók, ide értve a kórházakat is, napjainkban csak elvétve müködtetnek munkavállalóik egészségének megőrzése, fejlesztése érdekében tudatos, átfogó programokat. Az egészségügyi munkavégzés kedvezőtlen hatásait az egyének szintjén a rendszeres sporttevékenység, az egészséges táplálkozás mérsékelheti, emellett azonban szükséges lenne, hogy a munkahely is biztosítson sportolásra lehetőséget, egészséges ételekből álló menüt a menzán, az egészséges életmód felé irányító szaktanácsadást, szürővizsgálatokat, kikapcsolódásra alkalmat teremtő szervezett programokat. A munkahelyi egészségvédelem része kell(ene), hogy legyen a társadalmi felelősségvállalásnak, a kockázatértékelésnek és a minőségirányításnak. Ezeket a szempontokat a humánerőforrás stratégiába a vezetés szintjén szükséges beépíteni. Egy egészségtudatos munkahelyen nemcsak kevesebb a táppénzes nap, de hatékonyabb a munkavégzés is, így a munkáltató intézmény sikeresebbé és fenntarthatóbbá válhat.

Kutatásunk során az egyik legnagyobb magyarországi egészségügyi szolgáltató intézmény munkatársainak körében végeztünk sportolási szokásokra irányuló felmérést. Az eredmények hasonlóak az Eurobarometer (2018) felmérés Magyarországra vonatkozó adataihoz: a megkérdezett munkavállalók 54,9\%-a mondta azt, hogy nem sportol. Megállapítható, hogy jelen régióban is tovább kell keresni azokat a megoldásokat, amelyek a társadalom mind szélesebb rétegei számára teszik lehetővé, elérhetővé és az életmód részévé a rendszeres fizikai aktivitást. 


\section{Köszönetnyilvánítás}

A publikáció elkészítését az EFOP-3.6.2-16-2017-00003 számú projekt támogatta. A projekt az Európai Unió támogatásával, az Európai Szociális Alap társfinanszírozásával valósult meg.

\section{Irodalomjegyzék}

1. Ádám S, Győrffy Z, Harmatta J, Túry F, Kopp M, Szényei G. (2010): Psychiatric and somatic morbidity among Hungarian psychiatrists. Psychiatria Hungarica, (25), 1: 55-61.

2. Alacacioglu A, Yavuzsen T, Dirioz M, Oztop I, Yilmaz U. (2009): Burnout in nurses and physicians working at an oncology department. Psychooncology, (18), 5: 543-548. DOI: https://doi.org/10.1002/pon.1432

3. Al-Qahtani MF. (2015): Health-promoting lifestyle behaviors among nurses in private hospitals in Al-Khobar, Saudi Arabia. Journal of the Egyptian Public Health Association, (90), 1: 29-34. DOI: https://doi.org/10.1097/01.epx.0000461325.97703.8a

4. Bálint Mihály (1957): Az orvos, a betege és a betegség. Animula, Budapest.

5. Blake H, Harrison C. (2013): Health behaviours and attitudes towards being role models. British Journal of Nursing, (22), 2: 86-94. DOI: https://doi.org/10.12968/bjon.2013.22.2.86

6. Blake H, Malik S, Mo PK, Pisano C. (2011): „Do as say, but not as I do”: are next generation nurses role models for health? Perspectives in Public Health, (131), 5: 231-239. DOI: https://doi.org/10.1177/1757913911402547

7. Cubrilo-Turek M, Urek R, Turek S. (2006): Burnout syndrome--assessment of a stressful job among intensive care staff. Collegium Antropologicum, (30), 1: 131-135.

8. Csörsz Ilona (2011): Az orvosi hivatás személyiség alakulásának társaslélektani meghatározói és fejlesztésének lehetőségei, Doktori $(\mathrm{PhD})$ értekezés, Debreceni Egyetem BTK 2011. forrás: https://dea.lib.unideb.hubv/ dea/bitstream/handle/ 2437/111436/Csorsz_Ilona_Ertekezes.pdf?sequence $=5$ (letöltve: 2019. 03. 12.)

9. Detre Zoltán (2007): Sporttal a stressz, a szorongás és a depresszió ellen. Bólyai Szemle, (16), 1: 29-49.

10. Dewa CS, Loong D, Bonato S, Trojanowski L. (2017): The relationship between physician burnout and quality of healthcare in terms of safety and acceptability: a systematic review. BMJ Open. (7), 6: e015141. DOI: https://doi.org/10.1136/bmjopen-2016-015141

11. Egészségügyi Statisztikai Évkönyv 2014, Központi Statisztikai Hivatal, 2015.

12. Eke Edit, Girasek Edmond, Szócska Miklós (2009): A migráció a magyar orvosok körében, Statisztikai Szemle, (87), 7-8: 795-827.

13. Európai Unió (2013): Az egészségügyi ágazatban dolgozókat érintő munkahelyi egészségvédelmi és biztonsági kockázatok. Európai Bizottság, Foglalkoztatás, Szociális Ügyek és Társadalmi Befogadás Főigazgatósága, Luxembourg. 
14. Freudenberger, H.J. (1974): Staff burn out. Journal of Social Issues, (30), 1: 159-165. DOI: https://doi.org/10.1111/j.1540-4560.1974.tb00706.x

15. Győrffy Zsuzsa, Ádám Szilvia (2004): Az egészségi állapot, a munkastressz és a kiégés alakulása az orvosi hivatásban. Szociológiai Szemle, (14), 3: 107-127.

16. Győrffy Zsuzsa, Ádám Szilvia (2004): Az orvosnői hivatás magatartástudományi vizsgálata. Mentálhigiéné és Pszichoszomatika, (5), 1: 27-55. DOI: https://doi.org/10.1556/menta1.5.2004.1.2

17. Győrffy Zsuzsa, Ádám Szilvia (2013): Fiatal orvosnők testi-lelki egészsége Az emocionális kimerülés a hiányzó láncszem? Orvosi Hetilap, (154), 1: 20-27. DOI: https://doi.org/10.1556/oh.2013.29521

18. Hatfield BD. (1991): Exercise and mentalhealth: The mechanism of exerciseinduced Psychological states, In: Diamant L. [ed.], Psychology of sport, exercise and fitness. Social and personal issues. New York, Hemisphere Publishing Corporation. 17-49.

19. Johns MM, Ossoff RH. (2005): Burnout in academic chairs of otolaryngology: head and necksurgery. Laryngoscope. (115), 11: 2056-2061. DOI: https://doi.org/10.1097/01.mlg.0000181492.36179.8b

20. Kay MP, Mitchell GK, Del Mar CB. (2004): Doctors do not adequately look after their own physical health. Medical Journal of Australia, (181), 7: 368-370. DOI: https://doi.org/10.5694/j.1326-5377.2004.tb06329.x

21. Kirag N, Ocaktan EM. (2013): Analysis of health promoting lifestyle behaviors and associated factors among nurses at a university hospital inTurkey. Saudi Medical Journal, (34), 10: 1062-1067.

22. Lacy BE, Chan JL. (2018): Physician Burnout: The Hidden Health Care Crisis. Clinical Gastroenterology and Hepatology, (16), 3: 311-317. DOI: https://doi.org/10.1016/j.cgh.2017.06.043

23. Major János, Ress Katalin, Hulesch Bors, Túry Ferenc (2006): A kiégés jelensége az orvosi hivatásban. Lege Artis Medicinae, (16), 4: 367-373.

24. Mannocci A, Sestili C, Carnevale F, Minotti C, De Giusti M, Villari P, Foà R, Cartoni C, La Torre G. (2019): Assessment of burnout in healthcare personnel in hematological unit of a teaching hospital. Giornale Italiano di Medicina del Lavoro ed Ergonomia, (41), 1: 45-51.

25. Molnár László, Mezey Mária (1991): Az orvosok megbetegedéséről és halandóságáról. I. rész. Lege Artis Medicinae, (1), 8: 524-528.

26. Norris R, Carroll D, Cochrane R. (1992): The effects of psychical activity and exercise trainingon psychological stress and well-being in adolescent population. Journal of Psychosomatic Research, (36), 1: 55-65. DOI: https://doi.org/10.1016/0022-3999(92)90114-h

27. Papp Szidónia, Túry Ferenc (2010): A pályakezdő orvosok jövőképe és egészségi állapota. Lege Artis Medicinae, (20), 6-7: 423-429.

28. Peterson U, Demerouti E, Bergström G, Samuelsson M, Åsberg M, Nygren Å. (2008): Burnout and physical and mental health among Swedish healthcare workers. Journal of Advanced Nursing, (62), 1:84-95. DOI: https://doi.org/10.1111/j.1365-2648.2007.04580.x

29. Phiri LP, Draper CE, Lambert EV, Kolbe-Alexander TL. (2014): Nurses' lifestyle behaviours, health priorities and barriers to living a healthy lifestyle: a 
qualitative descriptive study. BMC Nursing, (13), 1: 38 . DOI: https://doi.org/10.1186/s12912-014-0038-6

30. Reith TP. (2018): Burnout in United States Healthcare Professionals: A Narrative Review Cureus, (10), 12: e3681. DOI: https://doi.org/10.7759/cureus.3681

31. Rurik Imre, Szigethy Endre, Langmár Zoltán (2014): Medical doctors in Hungary: 30 years after graduation data on lifestyle, morbidity, demography and differences between specialties. Central European Journal of Public Health, (22), 3: 183-188. DOI: https://doi.org/10.21101/cejph.a3910

32. Schmidbauer W. (1977): Die Hilflosen Helfer. Rohwolt, Reinbeck.

33. Shaw, DL, Wedding, D, Zeldow PB, Diehl N. (2001): Special problems of medical students. In: Wedding D. [ed.], Behaviour and medicine. Hogrefe and Huber, Göttingen, 67-84.

34. Sonneck G (1982): Orvosok öngyilkossága és kiégettsége. Szenvedélybetegségek, (2), 1: 28-31.

35. Special Eurobarometer 472 (2017): Sport and physical activity. European Union, forrás: http://ec.europa.eu/commfrontoffice/ publicopinion/index.cfm/survey/ getsurveydetail/instruments/special/surveyky/2164; (letöltve: 2019. 03. 12.)

36. Steptoe A, Moses J, Edwards S, Mathews A. (1993): Exercise and responsivity to mental stress: Discrepancies between the subjective and psychological effects of aerobic training. Special issue: Exercise and psychological wellbeing. International Journal of Sport Psychology, 24: 110-129.

37. Terebessy András, Matyasovszky Melinda, Horváth Ferenc, Horosz Áron, Juhász Irén, Győrffy Zsuzsa (2016): A testmozgás szerepe az egészségügyi dolgozók egészségfejlesztésében. Orvosi Hetilap, (157), 39: 1563-1570. DOI: https://doi.org/10.1556/650.2016.30540

38. Vailant, GE, Sobowale NC, McArthur C. (1972): Some psychological vulnerabilities of physicians. New England Journal Medicine, (287), 8: 372-375. DOI: https://doi.org/10.1056/nejm197208242870802

39. Viszt Erzsébet (2006): Nemzetközi munkaerő-vándorlás és versenyképesség. In: Vértes A, Viszt E, [szerk.]: Stratégiai kutatások - Magyarország 2015. Tanulmányok Magyarország Versenyképességéről. Új Mandátum kiadó. Budapest.

40. WHO (2014): A universal truth: no health without a workforce. forrás: https:/www.who.int/workforcealliance/knowledge/resources/GHWA-

a_universal_truth_report.pdf; (letöltve: 2019. 03. 12.)

41. $\overline{\mathrm{W}} \mathrm{HO}$ (2015): Making progress towards health workforce sustainability in the WHO European Region. forrás: http://www.euro.who.int/_data/ assets/pdf_file/ 0005/ 287456/ Making-progress-towards-health-workforce-sustainability-in-theWHO-European-Region-rev1.pdf?ua=1; (letöltve: 2019. 03. 12.) 